\title{
Education About Standardization as the Foundation for the Expertise Development of SMEs
}

\author{
BILJANA LJ. TOŠIĆ, University of Belgrade, \\ Faculty of Organizational Sciences, Belgrade \\ IVANA S. MIJATOVIĆ, University of Belgrade, \\ Faculty of Organizational Sciences, Belgrade
}

Rewiev paper

UDC: 334.713:006

DOI: 10.5937/tehnika2104521T

\begin{abstract}
Considering that small and medium-sized enterprises (SMEs) are seen as the backbone of the global economy and the ones that (against all odds) stand to gain the most from using and developing standards, the study aims at exploring does expertise in standardization exist in SMEs. To collect data, the semistructured interview via e-mail was used, as it seems to be much more comprehensive than the questionnaire. To analyze data, the Critical Incident Technique (CIT) and the qualitative content analysis method were used as the most suitable methods for analyzing data from subject matter experts. The data collected from a total of 28 experts from 14 countries was analyzed. Finally, five conclusions were determined - (1) expertise resides in all SMEs, (2) ... but not the expertise in standardization, (3) ... so external experts might be needed to support them, (4) education about standardization is crucial for the development of expertise in standardization, (5) ... but only as a support for lifelong learning.
\end{abstract}

Key words: education about standardization, capacity building, expertise development, SMEs

\section{INTRODUCTION}

Considering that SMEs are usually described as „the backbone of the global economy" [1] - SMEs (against all odds) stand to gain the most from using and developing standards. Unfortunately, SMEs are neither using nor developing standards as much as they could or should be [2]. These authors explained an attitude of small business owners and managers - „I'm behind my production, my client does not like my delivery, my assistant is ill, I had to mend our machine last night, and my best foreman lost his left finger yesterday. I'm too busy to deal with quality, health, or whatever? Oh, environmental issues!" [2].

Compared to large enterprises, SMEs usually do not have a substantial amount of resources to spend on using and developing standards - usually, they do not have the time, competent employees, and money to engage in standards development [2]. Although there may be some reasonable explanation for such associations between financial constraints and costs of either

Author's address: Biljana Tošić, University of Belgrade, Faculty of Organizational Sciences, Belgrade, Jove Ilića 154

e-mail: biljana.tosic@fon.bg.ac.rs

Paper received: 14.07.2021.

Paper accepted: 21.07.2021. using or developing standards by SMEs - another reason that seems to be far more significant (although mostly underestimated) must be the lack of knowledge, skills, competence, and expertise in standardization ma-tters. Only by acquiring such knowledge, skills, competence, and expertise in standardization matters, smallsized enterprises can compete on an equal footing and achieve sustained success in today's global economy. Contrary to the conventional thinking that formal education about standardization alone shall be enough for acquiring knowledge, skills, competence, and expertise in standardization matters - when it comes to the small business community, the focus shall be on lifelong learning.

One of the most significant findings reported by the current state of research may be described as the „enormous gap between latent and manifest needs" for education about standardization [3]. This might be explained by the fact that standardization as such ,is neither a science nor even a generally accepted academic discipline" [4]. This seems to suggest that standards and standardization still have a long way to be fully embraced by the academic community, espe-cially considering that they cannot be seen as a part of the generally accepted disciplines, such as ,engi-neering or social sciences" [5]. Accordingly - contemporary organizations usually do not consider formal 
education about standardization as needed for merely executing some standardization-related tasks [6]. Following the same reasoning, one can attempt to argue if a lifelong career in standardization may be "an exception and generally not advisable" [6]. It may be reasonable to assume that such a career may not be „very attractive“ to most young engineers [7]. This might be explained by the fact that most stan-dardization experts did not actually start their careers in standardization - they were usually active in some domain-specific (mostly technical) area, so mostly ,they just stumbled upon standardization, fell into it, or were pushed into it" [7]. The global market seldom asks for education about standardization ... and yet again everyone still talks about the same lack of knowledge, skills, competence, and expertise in standardization matters. As stated by John Hill, Standards Manager and the founder of the ICES - ,companies and standards bodies need well-educated standardization experts" [3]. Following the same reasoning, Toshiaki Kurokawa, Ph.D. suggested that Japanese companies also face great difficulties to find and keep standardization experts [3]. Similarly, Doede Bakker speaking on behalf of the Dutch Trade Association concluded that organizations that tend to achieve a competitive advantage at the global market may ,develop relevant standards themselves" [3]. This might suggest that employees at all levels must be acquainted with the tremendous significance of standards and standardization for their businesses [3]. Given that employees who are currently active in standardization in their organizations may be retiring in the next couple of decades - the main concern may be if there will be enough successors [3]. As graduates are seen as decision-makers of the future - (formal) education about standardization shall be seen as crucial but only as a foundation for capacity building and expertise development of SMEs.

To date, formal education about standardization has received careful considerations, especially since most academics believe that once standardization is successfully introduced to the university curricula ,general awareness and appreciation of standards' benefits will automatically result" [7]. This may be one of the main reasons why most academics strive for embracing education about standardization at the university level, ,preferably as compulsory subject“ [7]. The same author suggested that we should not embrace education about standardization at the university level denoting that such graduates would ,become very narrowly specialized" and their career development opportunities may be very limited [7]. Instead, the main goal of such formal education shall be (only) to make more people aware of standards and standardization [7]. This seems to suggest that the main goal of such a formal education might be only raising awareness, contrary to the conventional thinking that formal education can do so much more.

To date, a lot has been done to support education about standardization - e.g. World Standards Day (every 14th October), annual workshops organized by the International Cooperation for Education about Standardization (ICES), meetings organized by the European Union Joint Initiative on Standardization (JIS) - Action 3 - Education about Standardization $(\mathrm{EaS})$, the Joint Working Group on Education about Standardization (JWG-EaS), the Standardization and Regulatory Techniques (START-Ed) Group for Education about Standardization, different national workshops organized by national standards bodies (NSBs) aimed at enhancing collaboration between NSBs and academia, global repositories of teaching materials developed by international and European Standards Developing and Setting Organizations (SDOs and SSOs), etc. Although a lot has been done - a vast majority of such initiatives are not (yet) broadly embraced by the academic community [4]. The same author suggested that most of the contents are usually onesided, mostly based on marketing, and not adequate for the academic community [4]. This might be explained by the fact that such initiatives usually start from a blank slate and do not consider "what was already done in that context" [4]. This may be one of the main reasons why only a few educational establishments at the European level still teach relevant standardizationrelated courses [8].

The number of universities/colleges that offer standardization-related courses at the European level usually lies ,somewhere between 10 and 30“ and such courses mostly enroll only a few students [3]. This may be explained by the fact that only a limited amount of standardization-related knowledge may be included only as a part of some specific courses as ,mechanical engineering, electrical engineering, information technologies, business administration and law") [8]. Unfortunately - universities still do not offer standardization-related knowledge about ,technological, economic, and social considerations" [8]. This may be one of the reasons why universities that offer courses on education about standardization may be found in „Asia - China, Japan, and Corea, but also in Thailand, and thanks to the common European-Asian 'Asia-Link' project on education about standardization - Indonesia, Sri Lanka, and Vietnam, as well“" [3]. Contrary - non-academic courses might be found in almost every country - mainly courses for the use of specific standards [3].

Considering that education about standardization at the university level may be scarce and not enough ,education about standardization should be offered in 
the form of continuing education ... and as far as the academic community is concerned - this means postgraduate teaching" [6].

Although students may be acquainted with some technical standards during their formal education at universities and colleges - ,new standards emerge and existing standards will be changed or withdrawn" so when they get hired by an SME (or large organization) they will need continuing edu-cation about standardization, as well [6]. Considering that "they are better off when they have had some education in standards as such" [6] - education about standardization shall be seen as crucial but only as a foundation for lifelong learning.

\section{METHODOLOGY}

The previous studies by [9] and [10] aimed at exploring perceptions of experts from formal organizations for standardization, professional and industrial associations, consortia, fora, educational establishments, and governmental organizations related to the significance of expertise in standardization for the internationalization of SMEs.

The main findings were derived from five Reserch Questions (RQs), especially considering:

(1) use of standards,

(2) participation in the standardization

process,

(3) expertise in standardization,

(4) education about standardization, and

(5) main sources for acquiring knowledge, skills, competence and expertise in standardization matters.

Although the main findings suggested that expertise in standardization shall be of tremendous significance for the internationalization of SMEs - "the experts' perceptions related to the existence of expertise in standardization in SMEs significantly differ" [10]. This means that - ,while some [experts] argued that expertise resides in all SMEs, others strongly suggested that expertise does not exist in SMEs" [10].

Considering that ,owners and managers of SMEs must have had some level of expertise that enabled them to start their business activities and successfully carry them forward" [10] - the question still remains can it be expertise in standardization?

To collect data - a semi-structured interview via email was used, following the recommendations by [11]. The data collection was administered in January 2020, as we collected ,a total of 28 answers from standardization experts from 14 countries“ - ,the United States of America, Canada, Australia, China, Japan, Switzerland, Belgium, Netherlands, Spain, Italy, France, Bulgaria, Lithuania, and Serbia“" [9].
To analyze data - Critical Incident Technique (CIT) was used, following the recommendations by [12]. Once critical incidents have been determined we used the qualitative content analysis method following the guidelines and recommendations by [13, 14]. The data collection and the data analysis were previously explained and described in detail by [9].

\section{RESULTS \& DISCUSSION}

When it comes to the existence of expertise in standardization in micro, small, and medium-sized enterprises - a total of 5 conclusions may be derived -

\subsection{Expertise resides in all SMEs ...}

As stated by P10 - "most SMEs have considerable expertise vested in a few owners and employees of that SME; SMEs are most often led by people who [must have] had a high level of expertise that enabled them to start their business activities and successfully carry them forward; the expertise resides in almost every SME; the challenge is to find ways by which that expertise can be used to develop a standard". This seems to suggest that expertise (or knowledge, skills, and competence as a foundation for such expertise) may be found in most SMEs. These results are consistent with the results of [15] - especially considering that owners and managers of small enterprises ,have knowledge in key areas of competencies and think they can compete using such knowledge". Contrary, such results are not consistent with the results of [16] who suggested that in SMEs - „there is no place for specialists“. These authors suggested that small enterprises „may take advice" from the external world, but such enterprises usually lack ,resources and expertise to take such complex technical decisions through a specialist channel" [16].

This may be explained by the fact that owners and managers of SMEs usually ,end up making most of the decisions, even the decisions about ban-king, technology, communications, credit facili-ti-es, office equipment, whether to buy a new radio for the factory floor, to the kind of stationery to order" - so they do not have time to be concerned with experts [16]. Although one can attempt to argue if Kirzner's theory on entrepreneurial vs. expert knowledge from about 20 years ago may still be relevant in today's global economy (e.g. Kirzner argued that the „entre-preneurs may not have such a domain-specific (expert) knowledge that experts may have, but it is the entrepreneur who recognizes the value and the opportunity of the expert knowledge“ ... accordingly, ,,it is the entrepreneur that hires the expert(s)" $)$, different authors agreed that the absorptive capacity of entrepreneurs shall be seen as crucial - ,along with their ability to recognize specialist knowledge" [17]. 


\section{2. ... but not the expertise in standardization ...}

As stated by $\mathrm{P} 2$ - ,experts in standardization are usually the professional staff involved in the standardization process, i.e. technical officers, secretaries or committee managers, etc.; experts and delegates participating in technical committees, are experts in their field of knowledge (e.g. electric equipment for ..., test method on ...) but often not [experts] in standardization, unless they have a leading position like convenors, chairs, etc.)". This seems to suggest that if one can succeed at finding expertise in a small-scale firm - it might just not be the expertise in standardization. These results are consistent with the results of [7] - especially considering that most experts in standardization are „usually active in a technical area, ... in many cases - they just stumbled upon standardization, fell into it, or were pushed into it". Since, compared to their larger counterparts, SMEs usually do not have a substantial amount of resources to spend on using and developing standards - developing expertise in standardization may not be seen as the current priority. These results are consistent with the results of [18] arguing that owners and managers of SMEs ,,seem to be too busy dealing with urgent tasks" to give standards and standardization a high priority. These results are also consistent with the results of [19] suggesting that motivation for standardization seems to be low in organizations (large and SMEs) „due to the relatively low attractiveness of the topic".

As stated by P10 - ,ideally, an SME would need and thus want to be involved in the development of an international standard; however, it is unrealistic to expect that SMEs have the time, knowledge and expertise by which they could take such a role". This seems to suggest that even if an SME wants to get involved (if standardization is made a high priority) there may not be competent employees ready or eager to assume some of the standardization-related roles. Additionally, most small business owners and managers ,usually do not know how to delegate" so they „end up making most of the decisions", even the decisions about using and developing standards that are usually „the responsibility of expert professionals in large firms" " 20$]$. These results are consistent with the results of [18] suggesting that large organizations may be expected to deal with standardization matters as „some of the responsibilities and authorities can often be distributed to the lower-level management".

As mentioned by P27 - ,participation in the standardization process brings many advantages, but SMEs usually don't have enough knowledge about the standards development process; participation can be an overwhelming and frustrating process for SMEs due to the lack of knowledge and skills in this field". This seems to suggest that even if an SME recognizes standardization as a key strategic activity and decides to get involved - it may still face severe limitations to take standardization-related activities seriously, in terms that large organizations might. This may denote the fact that standardization may be seen as ,a management burden for most SMEs“ [9] - especially, due to the same lack of knowledge, skills, competence, or expertise in standardization matters.

\section{3. ... so external experts are needed to support them}

As stated by P21 - ,since no one in a small firm has a sufficient level of standardization knowledge, external experts are usually needed to support them". This seems to suggest that due to the constant lack of resources and capabilities SMEs face daily - they may have to explore external sources of knowledge, skills, and competence as a foundation for expertise development. These results are consistent with the results of $[21,22]$ considering that due to severe resource constraints, SMEs are usually more apt to seek and acquire knowledge from external sources.

As stated by P15 - ,in general, the number of (low threshold) sources [for acquiring knowledge about standards] seems limited; turning to national standards bo-dies (for information or training), or - depending on the sector - sectoral expertise centers - seems to be the most accessible option; engaging external consultants could be the next but more expensive step". This may suggest that SMEs may need some kind of continuous support for acquiring knowledge, skills, competence, and expertise in standardization matters. Given severe limitations small firms face daily, such support shall genuinely come from external sources (e.g. organizations for standardization, professional/industrial associations, consortia, fora, educational establish-ments, even governmental organizations shall be seen as crucial for capacity building and expertise development of SMEs.

As suggested by P10 - ,the main sources of such information [main sources for acquiring knowledge, about standards] should come from the National Standards Body (NSB) but, given the lack of NSB's resources, that information is usually not available; universities should hopefully be able to fill that gap; university professors and lecturers who have the knowledge and expertise can pass that knowledge and expertise to a wide group of young people who can hopefully take that knowledge with them as they begin and advance their careers". This might suggest that to achieve a competitive advantage in today's global economy, SMEs must take advantage of fairly extensive courses, seminars, and training offered by formal organizations for standardization, professional and industrial associations, consortia, fora, educational 
establishments, and governmental organizations, especially aimed at capacity building and expertise development of small enterprises.

\subsection{Education about standardization is crucial for the development of expertise in standardization}

As suggested by P15 - ,university education [about standardization] should give experts (to be) a head start related to their awareness of the topic, its relevance, basic features, etc., also, it will increase their ability to identify standardization as a relevant area for their own (career) development". This might suggest that education about standardization shall be seen as crucial for young engineers to acquire some knowledge about standards in today's global economy. If engineers/graduates employed by SMEs (or large organizations) have already acquired some knowledge about standards at the university level, it may be easier for them to trace standards that might be relevant, obtain relevant standards, understand relevant standards, implement relevant standards and evaluate the implementation of relevant standards [2]. Accordingly, it may be easier for engineers to trace relevant sta-ndards development projects, to become involved (and remain effectively involved) in the standards develo-pment, to start new activities in the standards develo-pment, and to evaluate their active involvement in the standards development [2].

As mentioned by P17 - ,[university] education about standardization gives additional tools to all graduates that find themselves employed by SMEs (or large enterprises) to integrate standards communities faster and with the knowledge needed to fully benefit from the standardization process". These results are consistent with the results of [2] - considering that „students should be made aware of standards (standardization) since they are the future SME employees or SME founders“. According to [2] - „experience from Asia shows that two elements are crucial for the integration of standardization in the national educational system: (a) a national policy of education about standardization, and (b) long-term availability of staff to support universities and schools by training teachers, developing materials, access standards, terms of exams, etc.". These results are also consistent with the conclusions of the ICES workshop, suggesting that „the discussions highlight the enormous gap between latent and manifest needs for standardization education as the main challenge; countries like Korea, Thailand, and Turkey show that to bridge this gap, a national strategy is needed, as is a cooperation between a country's government, industry, national standards body, academia, and educational institutions" [3]. This may suggest that - the needs of different stakeholders must be taken into account for developing such a nati- onal strategy. These results are also consistent with the results of [6] - considering that students may benefit from acquiring knowledge about standards, especially since „many of them will have to do with standards“.

As stated by P2 - ,education about standardization at the university level helps to raise awareness among SMEs to use standardization as a tool for business; education is like a seed you need to plant to grow a sound tree, $\ldots$ there are several free educational sources available and ready to be used by SMEs for acquiring knowledge about standards, ... but it may be difficult for SMEs to use these sources unless they are aware of the use and the impact of the standardization". This might suggest that the university education about standardization may only be seen as one of the tools for raising awareness about standards and standardization in today's global economy, but not the only one. These results seem to be consistent with the results of [7] suggesting that only by raising awareness among young engineers about standards and standardization „we can ensure that knowledge about standardization will spread into our society and will be recognized and valued as structured common sense". Although we must agree that standardization can not be seen ,as a goal itself, but as a very useful supporting discipline" [7] one can attempt to argue if formal education about standardization at the university level shall only serve to make more graduates aware of standards and standardization. As stated by [7] - ,numerous are actions available for making the masses aware of the importance of standardization". So, does it have to be the main goal of university education, as well? These results are consistent with the results of [4] given that ,learning outcomes of education about standardization in higher education may be significantly higher than raising awareness".

As stated by P26 - ,standards as a means of capturing and disseminating knowledge, can make a positive contribution to the economy, growth, and prosperity; education about standardization at the university level is directly related to the development of expertise in standardization of SMEs, especially at a time when organizations need more innovation to remain competitive on the global stage". This may suggest that formal education about standardization at the university level shall be seen as crucial, but only as the foundation for capacity building and expertise development of small firms.

\section{5. ... but only as a support for lifelong learning}

As suggested by P7 - ,education is a good foundation, but it needs to be upgraded quite a bit for this knowledge to be applicable in a particular work environment". This may be explained by the fact that although education about standardization seems crucial - 
when it comes to the small business community - the focus shall be on lifelong learning. These results are consistent with the results of [3] - considering that ,such knowledge may not suffice, as new standards emerge and existing standards are changed or withdrawn, so once people really get involved in developing or applying standards in their professional life they will need continuous education [lifelong learning], e.g. by means of course offered by NSBs". These results are also consistent with the results of [3] since ,people who do the standards work (e.g. who participate in standards committees) - mostly do so without any education and training“",... so they are not aware that continuing education ,could enhance their effectiveness considerably“.

As stated by P14 - ,SMEs would benefit most from a comprehensive textbook; a really good one is not available; current books are one-sided, especially those prepared by standards bodies, or too difficult; 'Standardization for Dummies' is not available“. These results are consistent with the results of [3] - considering that ,a vast majority of books, e-learning environments, digital lectures and internet courses, bibliographies, and teaching cases ... are written in Chinese, Dutch, Japanese, Korean, Turkish, etc. and as such are not easily accessible“. This may suggest that only a small amount of standardization-related litera-ture is written in English and is understandable across the globe. These results are consistent with the results of [6] - suggesting that even though ,the number of textbooks in standardization has risen ... considering the number of people that spend time developing or using standards, it is just a beginning".

As stated by P25 - ,,some of the major standards development organizations have fairly extensive training programs, so staff from SME's that are going to be involved in standards with these bodies do have options; if the standard is being developed by a smaller standards body they may not have training or education options; as an alternative, universities are beginning to offer continuing education programs which may include modules on standards, but these are still rather small in number currently“.

This might suggest that formal education about standardization and such con-tinuing education about standardization are still scarce and not enough. There is enough evidence to suggest that "education about standardization must find its place in formal higher education and lifelong learning, ... to have future professionals who can use their knowledge about standards and standardization for technology transfer, economic growth, global sustai-nability, or - in the case of latecomer countries - for strategies of 'accept and learn' or of (technology),,catch up“ [4].

\section{CONCLUSION}

Our findings suggested that expertise exists in all SMEs (but not the expertise in standardization), ... so external experts might be needed to support them.

This might suggest that SMEs may need some kind of continuous and long-lasting support aimed at capacity building \& expertise development of SMEs.

Our results suggested that the gap can be bridged - first by the formal education about standardization at the university level and, second, by the continuing education about standardization (lifelong learning). Contrary to the conventional thinking that formal education shall be enough for acquiring knowledge, skills, competence, and expertise in standardization - when it comes to the small business community, the focus shall unanimously be on lifelong learning.

Two aspects shall be paid careful considerations first, speaking about acquiring knowledge, skills, and competence in standardization matters - the question remains - will such knowledge, skills, and competence be enough for expertise development? SMEs may attempt to acquire some basic knowledge about standards (e.g. quality/environmental aspects) - but will it be enough for developing the expertise? Second, as an outstanding performance shall be seen as the characteristic of the expertise [23] - a que-stion may be - are SMEs capable of outstanding per-formance? The same author explained that - ,what is generally accepted from employees is a minimum ac-ceptable level of performance“ - and ,what is desired is an outstanding performance" [23]. This seems to su-ggest that to be competitive and achieve sustained success in today's global economy - organizations mu-st tend to develop expertise [23].

Offering continuous support to small enterprises shall not start from the blank slate but shall consider solutions already available to SMEs around the world. Only through the successful collaboration of stakeholders from organizations for standardization, professional and industrial associations, consortia, fora, educational establishments, and governmental organizations, continuous and long-lasting support for small businesses shall be successfully co-created.

\section{ACKNOWLEDGEMENTS}

The studies based on the same data collection (and with different content) were previously published by the EURAS 2020 and the EURAS 2021 Proceedings $[9,10]$.

\section{REFERENCES}

[1] El Madani A. SME Policy: Comparative Analysis of SME Definitions, International Journal of Academic 
Research in Business and Social Sciences, 8(8), 103 114, 2018, https://doi.org/10.6007/IJARBSS/v8i8/4443

[2] De Vries HJ, Blind K, Mangelsdorf A, Verheul H, Van der Zwan J. SME access to European Standardization: Enabling Small and Medium-Sized Enterprises to achieve Greater Benefit from Standards and from Involvement in Standardization, Rotterdam School of Management, Erasmus University, Rotterdam, the Netherlands, August 2009, [Internet], Dostupno na: https://-www.unms.sk/-swift_data/-source/dokumenty/technicka_normalizacia/msp/SMEAccessReport.pdf.

[3] De Vries H. J, Egyedi T. M, Education about Standardization. International Journal of IT Standards and Standardization Research, 5(2):1-16, June 2007, https://doi.org/10.4018/jitsr.2007070101

[4] Mijatović I. Teaching Standardization to Generation Z - Learning Outcomes Define Teaching Methods, In Idowu SO, De Vries HJ, Mijatović I, Don-ggeun C (Eds.), Sustainable Development: Know-ledge and Education about Standardization (CSR, Susta). Springer. https://doi.org/10.1007/978-3-030-287153_12, 2019.

[5] De Vries H. J, Standardization: A Business Approach to the Role of National Standardization Organizations. Springer Science+Business Media, LLC, https://www.springer.com/gp/book/9780792386384, 1999 ,

[6] De Vries HJ. Standardization Education. In Holler MJ \& Niskanen E (Eds.) EURAS Yearbook of Standardization, Vol. 5. Special issue of Homo Oecunomicus, 22, 1, 71-91, 2005.

[7] Simons CAJ. Education in Standardization - Getting structured common sense into our society - The personal opinion of standards educator, ISO Bulletin, June [Internet], Dostupno na: https://www.iso.org/files/live/sites/isoorg/files/archive/pdf/en/article_bul 1_june_99_-_educ_in_stdzation.pdf. 1999,

[8] Hesser W. The quality of teaching in the subject of standardization at universities - a factor for the competitiveness of the economy in Europe, Helmut Schmidt Universität, Hamburg, Germany, June 2014.

[9] Tošić B, Mijatović I, The Impact of the Expertise in Standardization on the Internationalization of SMEs - The Perception of Experts, [Internet], Dostupno na: (Eds.), EURAS Proceedings, 10-12 June 2020, Glasgow, Scotland, pp. 287-306, 2020, [Internet], Dostupno na: https://static-curis.ku.dk/-portal/files/-250968079/EURAS_2020_bearbeitung.pdf, 2020
[10]Mijatović I, Tošić B, Demystifying the Expertise: Ex-pertise in Standardization in SMEs as the Common Goal. In Jacobs K \& Dong-hyu K (Eds.), EURAS Proceedings (forthcoming), 2021.

[11]Kallio H, Pietilä AM, Johnson M, Kangasniemi M. Systematic methodological review: developing a framework for a qualitative semi-structured inter-vi-ew guide, In Journal of Advanced Nursing, 72-(12):-2954-2965,https://-doi.org/-10.1111/-jan.-13031, 2016,

[12]Gremler D. D, The Critical Incident Technique in Service Research. Journal of Service Research, Vol. 7, No. 1, pp. 65-89, August 2004, [Internet], Do-stupno na: http://home.ubalt.edu/-tmitch/651/-pdf\%-20articles/critical\%20incident $\% 20$ job\%20analysis $\% 20$ 2004.pdf (https://-doi.org/10.1177/-1094670-504-266138).

[13]Forman J, Damschroder L, Qualitative Content Analysis. Theoretical Foundation. Empirical Methods for Bioethics: A Primer, Advances in Bioethics, Vol. 11, pp. 39-62, https://doi.org/10.1016/S1479-370-9(07)11003-7, 2007,

[14]Stemler S, An overview of content analysis, Practical Assessment, Research, and Evaluation, Vol. 7, Article 17, [Internet], Dostupno na: https://-scholarworks.umass.edu/cgi/viewcontent.cgi? article $=1100$ \&context=pare (https://doi.org/-10.72-75/z6fm-2e34), June 2001.

[15]Desouza K. C, Awazu Y, Knowledge management at SMEs: Five peculiarities. Journal of Knowledge Management, Vol. 10, No. 1, pp. 32-43, https://-doi.org/10.1108/13673270610650085, 2006,

[16]Culkin N, Smith D. An emotional business: A guide to understanding the motivations of small business decision takers. Qualitative Market Research, Vol. 3, No. 3, pp. 145-157, 2000, https://-doi.org/-10.1108/13522750010333898

[17]Hutchinson V, Quintas P. Do SMEs do knowledge management?: Or simply manage what they know? International Small Business Journal, 26(2), pp. 131-154, https://doi.org/-10.1177/0266242-6070-86571, 2008,

[18]Yew Wong K, Aspinwall E, Characterizing knowledge management in the small business environment. Journal of Knowledge Management, 8(3), pp. 44-61, https://doi.org/10.1108/13673270410541033,2004 ,

[19]Blind K, Dreschler S, European Market Needs for Education in Standardisation: Standardisation-related Competence, Directorate-General for Internal Market, Industry, Entrepreneurship and SMEs (European Commission), Berlin and Karlsruhe, 91 p, 
[Internet], Dostupno na: https://-op.europa.eu/-en/publication-detail/-/publica-tion/c-013b068-e08411e7-9749-01aa75ed71a1/, October 2017,

[20]Haksever C, Total Quality Management in the small business environment. Business Horizons, 39(2), pp. 33-40, https://doi.org/10.1016/S00076813(96)9002$1 \mathrm{X}, 1996$,

[21]Cantú L. Z, Criado J. R, Criado AR. Generation and transfer of knowledge in IT-related SMEs. Journal of
Knowledge Management, 13(5), pp. 243-256, https://doi.org/10.1108/13673270910988088, 2009,

[22]Durst S, Edvardsson IR. Knowledge management in SMEs: A literature review. Journal of Knowledge Management, 2012.

[23]Herling R. W. Operational Definitions of Expertise and Competence. Advances in Developing Human Resources, 2(1), pp. 1-7, https://doi.org/-10.-1177/$152342230000200103,2000$.

\section{REZIME}

\section{OBRAZOVANJE O STANDARDIZACIJI KAO OSNOVA ZA RAZVOJ EKSPERTIZE U MSP}

S obzirom na to da mala i srednja preduzeća (MSP) predstavljaju okosnicu globalne ekonomije i da su (uprkos svemu) upravo MSP ona koja mogu ostvariti najviše koristi kako od korišćenja (primene standarda), tako i od donošenja standarda (učestvovanja u procesu standardizacije) - ovaj rad ima za cilj da istraži da li ekspertiza iz oblasti standardizacije zapravo postoji u MSP. Za prikupljanje podataka je korišćen delimično-strukturisani intervju putem elektronske pošte, s obzirom na to da on može biti znatno opširniji od upitnika (ankete). Za analiziranje podataka su korišćene tehnika kritičnih incidenata i kvalitativna analiza sadržaja, s obzirom na to da su ove metode najprikladnije za analiziranje podataka dobijenih od eksperata za pojedine oblasti. Podaci prikupljeni od ukupno 28 eksperata iz 14 zemalja sveta su dalje analizirani. Konačno, pet zaključaka je izvedeno - (1) ekspertiza postoji u svim MSP, (2) ... ali ne ekspertiza iz oblasti standardizacije, (3) ... pa bi im mogla biti potrebna pomoć spoljnih (eksternih) eksperata, (4) obrazovanje o standardizaciji je ključno za razvijanje ekspertize iz oblasti standardizacije, (5) ... ali samo kao podrška celoživotnom učenju.

Ključne reči: obrazovanje o standardizaciji, izgradnja kapaciteta, razvoj ekspertize, MSP 